\title{
Compositional differences between Besko and Otryt sandstones of the Krosno Beds (Oligocene) in Eastern part of the Silesian Tectonic Unit
}

\author{
Paweł Godlewski, Marek Wendorff, Andrzej Świąder \\ AGH University of Science and Technology, Faculty of Geology, Geophysics and Environmental Protection; al. A. Mickiewicza 30, \\ 30-059 Krakow, Poland; e-mail: pawel.godlewski.agh@gmail.com,wendorff@agh.edu.pl,andrzej.swiader@agh.edu.pl
}

(c) 2016 Authors. This is an open access publication, which can be used, distributed and reproduced in any medium according to the Creative Commons CC-BY 4.0 License requiring that the original work has been properly cited.

The Krosno Formation (Oligocene) in the Silesian Tectonic Unit of the E part of the Polish Outer Carpathians is represented by two lithofacies called the Besko (or Lesko) and the Otryt facies. Their mineral composition was analysed in the past at a broad regional scale (Schideler et al. 1975) and the depositional mechanism for each facies was interpreted on the basis of sedimentary features observed on the outcrop (Ślączka \& Unrug 1972, Wendorff 1987). Each of the two lithofacies forms an individual complex of strata supplied from two different source areas by turbidity currents of different hydrodynamic characteristics (Wendorff 1981, 1987). Namely, the strata of the Besko/Lesko lithofacies were interpreted as deposits of normally diluted and gradually decelerating, SE-oriented turbidity currents originating from the Silesian Ridge in the NW. On the other hand, the Otryt lithofacies is represented by deposits of rapidly decelerating high-density turbidity currents running in the opposite direction and derived from the Maramures Massif in the SE (Ślączka \& Unrug 1972).

The scope of this reconnaissance study is to investigate under petrographic microscope grain size, grain orientation and mineral composition of selected samples of the two sandstone types described above. These features and their comparisons should reveal whether the differences in transport and deposition mechanisms between the two lithofacies, which were in the past interpreted on the basis of macroscopic observations, are reflected by the microscopically observable features. For this purpose, and considering the reconnaissance character of this work, vertical sections of two sandstone beds were sampled in the area of the Otryt Syncline (in the Bieszczady Mts.) where these two lithofacies complexes are present. For each bed, one sample represents its lowermost part and another uppermost part. Therefore the textural characteristics of each pair of samples document hydrodynamic variations between the initiation and the final stage of deposition of the sampled bed. This is because various transport and deposition mechanisms of sediment gravity flows, and their gradients, result in differences in grain size, grain size sorting and grain orientation within a bed.

The diversity of mineral composition between Besko and Otryt lithofacies is very clearly recorded in the analysed thin sections, which remains in agreement with the data published earlier and reflects different mineral composition of the respective source areas (Ślączka \& Unrug 1972, Shideler et. al. 1975). The sample of the Besko lithofacies sandstone is characterised by high textural and mineralogical maturity (well-rounded grains and high quartz content). The bottom sample is moderately well sorted (standard deviation 0.64 ) and the top sample is moderately sorted (standard deviation 0.95). Graphic mean grain size for the bottom sample is 3.20 (Bouma Tb interval), and for the top 
sample 3.76 (Bouma Tc interval; both values being expressed in phi scale units). Therefore the upper sample represents deposition from a more diluted current (of lower flow competence) than the bottom sample. Less good sorting in the finer grained upper sample reflects pronounced contrasts in grain-size between individual laminae of the current-ripple cross-laminated Tc interval.

Both samples of the Otryt facies sandstone show relatively high content of unstable grains, therefore this rock has low mineralogical maturity. Except for solitary well-rounded coarse grains, the bulk of grains are poorly rounded, which documents low textural maturity. The bottom sample of the Otryt facies is richer in grains of coarse to very coarse metamorphic rock fragments and polycrystalline quartz than the top-of-bed sample. Texturally, both samples are poorly sorted. This is shown by very similar standard deviation values (bottom 1.18; top 1.12). The values of graphic mean grain size range from 1.68 (bottom) to 1.92 (top). Furthermore the grain-size distribution curve of the sample from the bed bottom is characterised by coarse-tail, whereas the upper sample distribution is devoid of coarse-tail. These values and their distributions imply grain-size sorting by a high-density turbidity current unable to separate the various grain-size classes present in the flow. In such flows only the coarsest fraction is present initially but the remaining spectrum of the grains remains unchanged throughout the depositional process (Shideler et. al. 1975).
A comparison between the two sets of samples shows the influence of two different flow types expressed by notable differences in grain size and sorting. The Besko facies sandstone is finer grained due to having been deposited from a more diluted current of lower competence. Furthermore, the Besko facies sandstone must have been deposited from a gradually decelerating current whereas the Otryt facies sandstone was deposited rapidly by denser turbidity current in which grain-size sorting affected only the coarsest grains. As a consequence grain orientation parallel to the flow direction is more distinct in the Besko facies than in the Otryt facies sandstones.

\section{REFERENCES}

Schideler G., Ślączka A., Unrug R. \& Wendorff M., 1975. Textural and mineralogical sorting relationship in krosno formation (Oligocene) turbidites, Polish Carpathian Mountains. Journal of Sedimentary Petrology, 45, 1, $44-56$.

Ślączka A. \& Unrug R., 1972. Ocena regionalnej i lokalnej zmienności składu piaskowców warstw krośnieńskich metodą analizy wariacyjnej [with English abstract]. Rocznik Polskiego Towarzystwa Geologicznego, 42, 373-395.

Wendorff M., 1981. Lower Krosno Beds (Polish Carpathians) - an example of two interfingering submarine fans. Nieuwsbrief Kon. Nederl. Geo. Mijnh. Gen., 8.

Wendorff M., 1987. Facies relationship in the Krosno Beds in the eastern part of the Silesian tectonic unit: an outline of qualitative and quantitative analysis. [in:] Teisseyre A.K. (ed.), 7th European Regional Meeting: Kraków - Poland, May 1986: excursion guidebook, Ossolineum, Wrocław, 121-125. 